\title{
Denitrification, anaerobic ammonium oxidation, and dissimilatory nitrate reduction to ammonium in an East African Great Lake (Lake Kivu)
}

\author{
Fleur A. E. Roland (D), ${ }^{1 *}$ François Darchambeau, ${ }^{1}$ Alberto V. Borges, ${ }^{1}$ Cédric Morana, ${ }^{2}$ \\ Loreto De Brabandere, ${ }^{3}$ Bo Thamdrup, ${ }^{4}$ Sean A. Crowe ${ }^{5}$ \\ ${ }^{1}$ Chemical Oceanography Unit, Université de Liège, Liège, Belgium \\ ${ }^{2}$ Department of Earth and Environmental Sciences, Katholieke Universiteit Leuven (KU Leuven), Leuven, Belgium \\ ${ }^{3}$ Analytical and Environmental Chemistry, Vrije Universiteit Brussel, Brussel, Belgium \\ ${ }^{4}$ Institute of Biology and Nordic Center for Earth Evolution, University of Southern Denmark, Odense, Denmark \\ ${ }^{5}$ Department of Earth, Ocean and Atmospheric Sciences, University of British Columbia, Vancouver, Canada
}

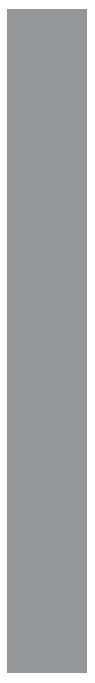

\begin{abstract}
We investigated anaerobic nitrogen $(\mathrm{N})$ cycling in the water column of Lake Kivu, a deep meromictic tropical lake in East Africa. Data were collected at one station in the Northern Basin and one in the Southern Basin, during two sampling campaigns (June 2011—dry season, and February 2012—rainy season). Shortterm incubations of sulfide-free water with ${ }^{15} \mathrm{~N}$-labeled substrates revealed high potential denitrification and dissimilatory nitrate reduction to ammonium (DNRA) rates (up to 350 and 36 nmol N produced $\mathrm{L}^{-1} \mathrm{~h}^{-1}$,

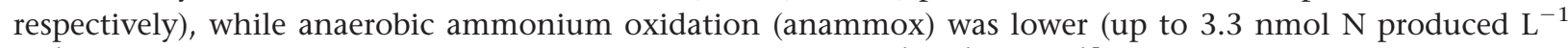
$\mathrm{h}^{-1}$ ). However, anammox rates were $15 \mathrm{nmol} \mathrm{N}$ produced $\mathrm{L}^{-1} \mathrm{~h}^{-1}$ when ${ }^{15} \mathrm{NH}_{4}^{+}$was added at depths where $\mathrm{NH}_{4}^{+}$concentrations were very low $\left(<1 \mu \mathrm{mol} \mathrm{L}{ }^{-1}\right)$. With the addition of $5 \mu \mathrm{mol} \mathrm{L}{ }^{-1}$ of ${ }^{15} \mathrm{NO}_{3}^{-}$and $10 \mu \mathrm{mol}$ $\mathrm{L}^{-1}$ of $\mathrm{H}_{2} \mathrm{~S}$, denitrification and anammox were stimulated in the Northern Basin, while the increase of DNRA rates was less notable. In the Southern Basin, the addition of $\mathrm{H}_{2} \mathrm{~S}$ decreased denitrification rates, probably because of competition with DNRA, which increased, while no effect was observed on anammox. This study puts into evidence the co-occurrence of denitrification, anammox and DNRA, for the first time in a great tropical lake, and underlines the spatial heterogeneity of these processes. Contrary to numerous reports in literature, we show that anammox can significantly occur in presence of $\mathrm{H}_{2} \mathrm{~S}$, suggesting that the contribution of anammox in the $\mathrm{N}$ cycle may be underestimated.
\end{abstract}

As an element required for life, the availability of nitrogen (N) can limit biological growth and ecosystem productivity. $\mathrm{N}$ is cycled through the biosphere via a number of microbial-mediated processes including biological fixation of $\mathrm{N}_{2}$ gas, nitrification, denitrification, anaerobic ammonium oxidation (anammox), and dissimilatory nitrate reduction to ammonium (DNRA). Human activities, notably the use of fertilizers and farming of $\mathrm{N}$-fixing crops (e.g., soybeans), have disrupted the pre-Anthropocene $\mathrm{N}$-cycle by increasing total global fixed $\mathrm{N}$ pool as well as nitrous oxide $\left(\mathrm{N}_{2} \mathrm{O}\right)$ emissions to the atmosphere (IPCC 2013). $\mathrm{N}_{2} \mathrm{O}$ is both a potent greenhouse gas and an ozone depleting agent, and its atmospheric concentrations had risen by $20 \%$ in 2011 compared

*Correspondence: froland@ulg.ac.be

Additional Supporting Information may be found in the online version of this article. to 1750 (IPCC 2013). Effective prediction and management of ecosystem responses to perturbations of the $\mathrm{N}$-cycle requires detailed knowledge of the processes responsible for $\mathrm{N}$-cycling and the ultimate removal of fixed $\mathrm{N}$ back to the atmosphere.

Three anaerobic metabolisms are responsible for nitrate $\left(\mathrm{NO}_{3}^{-}\right)$or nitrite $\left(\mathrm{NO}_{2}^{-}\right)$reduction: canonical denitrification, anaerobic ammonium oxidation (anammox), and dissimilatory reduction of nitrate to ammonium (DNRA). These three processes have markedly different impacts on the N-cycle: denitrification and anammox lead to $\mathrm{N}_{2}$ production and ecosystem N-loss, denitrification produces $\mathrm{N}_{2} \mathrm{O}$ as an intermediate in the chemical reaction chain; DNRA leads to $\mathrm{N}$ retention as $\mathrm{NH}_{4}^{+}$, promoting $\mathrm{N}$ recycling. Knowledge on the regulation of these competing processes is crucial for predicting, modeling, and managing the $\mathrm{N}$-cycle.

Canonical denitrification is commonly observed in rivers, streams, estuarine and marine sediments, and in anoxic lake 
waters (Seitzinger 1988). It can be heterotrophic, with organic matter as electron donor, or chemolithotrophic with iron, sulfur compounds, methane, or hydrogen as electron donors (Kirchman et al. 2008). While heterotrophic denitrification is generally assumed to operate ubiquitously in anoxic marine and freshwater sediments, observation of chemolithotrophic denitrification with $\mathrm{H}_{2} \mathrm{~S}$ come mostly from marine sediments (Jensen et al. 2009; Lavik et al. 2009; Canfield et al. 2010), and some marine oxygen minimum zones such as the Chilean upwelling system and the Baltic Sea (Canfield et al. 2010; Dalsgaard et al. 2013). Nevertheless, some studies suggest that chemolithotrophic denitrification could account for $25-40 \%$ of the $\mathrm{N}$ loss from streams, wetlands and lakes (Burgin and Hamilton 2008), and though direct measurements of the process exist (e.g., Lake Lugano; Wenk et al. 2013) they are to-date limited. While heterotrophic denitrification has been widely described, the cooccurrence and regulation of denitrification and other anaerobic metabolisms, such as anammox and DNRA, remains uncertain across freshwater and marine environments. Anammox is an autotrophic process, constituting a competitive advantage compared to heterotrophic denitrification (Hulth et al. 2005), and is known to be more oxygen tolerant (Kuypers et al. 2005; Jensen et al. 2008), allowing it to occur in a wider variety of environments. However, the efficiency of the process is reduced, since anammox bacteria have a slow growth rate (Jetten et al. 1998, 2001; Hulth et al. 2005). DNRA competes with denitrification for $\mathrm{NO}_{3}^{-}$, with DNRA expected to dominate in environments with a high organic matter : fixed $\mathrm{N}$ ratio, whereas higher $\mathrm{NO}_{3}^{-}$concentrations may favor denitrification (Kelso et al. 1997; Silver et al. 2001; Dong et al. 2011). As anaerobic processes, the three processes are regulated, in part, by $\mathrm{O}_{2}$ concentration, as well as the availability of the different substrates (organic matter, $\mathrm{NO}_{2}^{-}, \mathrm{NO}_{3}^{-}, \mathrm{NH}_{4}^{+}, \mathrm{HS}^{-}$), both determining the competitive relationships.

Denitrification, anammox, and DNRA are all known to be enhanced at high temperatures (Saad and Conrad 1993; Van Hulle et al. 2010; Dong et al. 2011). Tropical lakes represent only a areal small fraction of lakes globally (Lewis 2000) but are characterized by high mean annual temperatures that may support a disproportionally large role in global biogeochemical cycling (Lewis 1987). The N-cycle in tropical freshwaters, and in particular in tropical great lakes, however, remains understudied. The co-occurrence of denitrification, anammox, and DNRA, and their regulation have been poorly examined. We investigated one of the East-African Great Lakes, Lake Kivu, located at the border between Rwanda and the Democratic Republic of Congo. Lake Kivu is characterized by deep waters rich in $\mathrm{NH}_{4}^{+}$, carbon dioxide, and methane (Schmid et al. 2005). Compared to temperate lakes, tropic lakes exhibit minimal seasonality of their physicochemical parameters. In Lake Kivu, the dry season (from June to September) is accompanied by a deeper mixing of the oxygenated surface waters (i.e., the mixolimnion), compared to the rainy season. During the rainy season, $\mathrm{NO}_{3}^{-}$ accumulates at the base of the mixed-layer, forming a nitrogenous zone (also described as a nitracline) (Llirós et al. 2010; Pasche et al. 2011) where $\mathrm{N}_{2} \mathrm{O}$ accumulates (Roland et al. 2016), indicating active $\mathrm{N}$-cycling. A zone of sulfate $\left(\mathrm{SO}_{4}^{2-}\right)$ reduction is present below the oxic-anoxic interface, leading to $\mathrm{HS}^{-}$accumulation to concentrations up to $200 \mu \mathrm{mol} \mathrm{L}{ }^{-1}$ in the anoxic waters (Pasche et al. 2011; Morana et al. 2016). Fluxes of $\mathrm{HS}^{-}$from these deeper waters into the nitrogenous zone could support denitrification coupled to $\mathrm{HS}^{-}$oxidation. Furthermore, as the deep waters of Lake Kivu are also rich in $\mathrm{NH}_{4}^{+}$, fluxes of $\mathrm{NH}_{4}^{+}$into the nitrogenous zone could fuel anammox. To test these hypotheses, and bring new data and knowledge on $\mathrm{N}$-cycling in tropical lakes, we conducted a suite of process rate measurements, as well as geochemical and microbiological analyses over two seasons and at two stations in Lake Kivu. Only the water column was sampled, since most anaerobic processes are expected to occur in the water column close to the oxic-anoxic interface where terminal electron acceptors are generated $\left(\mathrm{NO}_{3}^{-}, \mathrm{SO}_{4}^{2-}\right.$, etc.). Indeed, the shores of Lake Kivu are very steep, consequently most of the lake is very deep ( $>80 \%$ of lake has a depth $>200 \mathrm{~m}$, average depth is $244 \mathrm{~m}$ ). The sedimentary anaerobic processes other than methanogenesis are thus expected to be negligible and to mainly occur in the upper anoxic water column.

\section{Material and methods}

\section{Sampling and physico-chemical parameters}

Sampling campaigns were conducted during the dry season (June 2011) and rainy season (February 2012), at two stations; one in the Northern Basin $\left(-1.72504^{\circ} \mathrm{N}, 29.23745^{\circ} \mathrm{E}\right)$ and one in the Southern Basin $\left(-2.3374^{\circ} \mathrm{N}, 28.9775^{\circ} \mathrm{E}\right)$ (Fig. 1). The maximum depths at the sampled stations are $250 \mathrm{~m}$ and $120 \mathrm{~m}$ in the Northern and Southern Basins, respectively.

Water column was sampled with a vertical 7 L Niskintype bottle (Hydro-Bios) at $5 \mathrm{~m}$ intervals from the surface to $80 \mathrm{~m}$ for chemical water analyses. For $\mathrm{N}$ stable isotope labeling experiments, water was collected with a higher spatial resolution (at $2.5 \mathrm{~m}$ intervals) in a $10 \mathrm{~m}$ zone, located $5 \mathrm{~m}$ above and $5 \mathrm{~m}$ below the oxic-anoxic interface.

Vertical profiles of temperature, conductivity, $\mathrm{pH}$, and oxygen were obtained with a Yellow Springs Instrument 6600 V2 multiparameter probe. The $\mathrm{pH}$ probe malfunctioned in June 2011. Therefore, the $\mathrm{pH}$ data presented for this campaign were measured with a portable $\mathrm{pH}$ meter and a Metrohm $\mathrm{pH}$ electrode on water sampled from the Niskin bottles.

\section{$\mathrm{N}$ stable isotope labeling experiments}

Water was collected in duplicate in amber $250 \mathrm{~mL}$ borosilicate bottles from the Niskin bottle with tubing, left to overflow three times the bottle volume, and sealed with Teflon-coated 


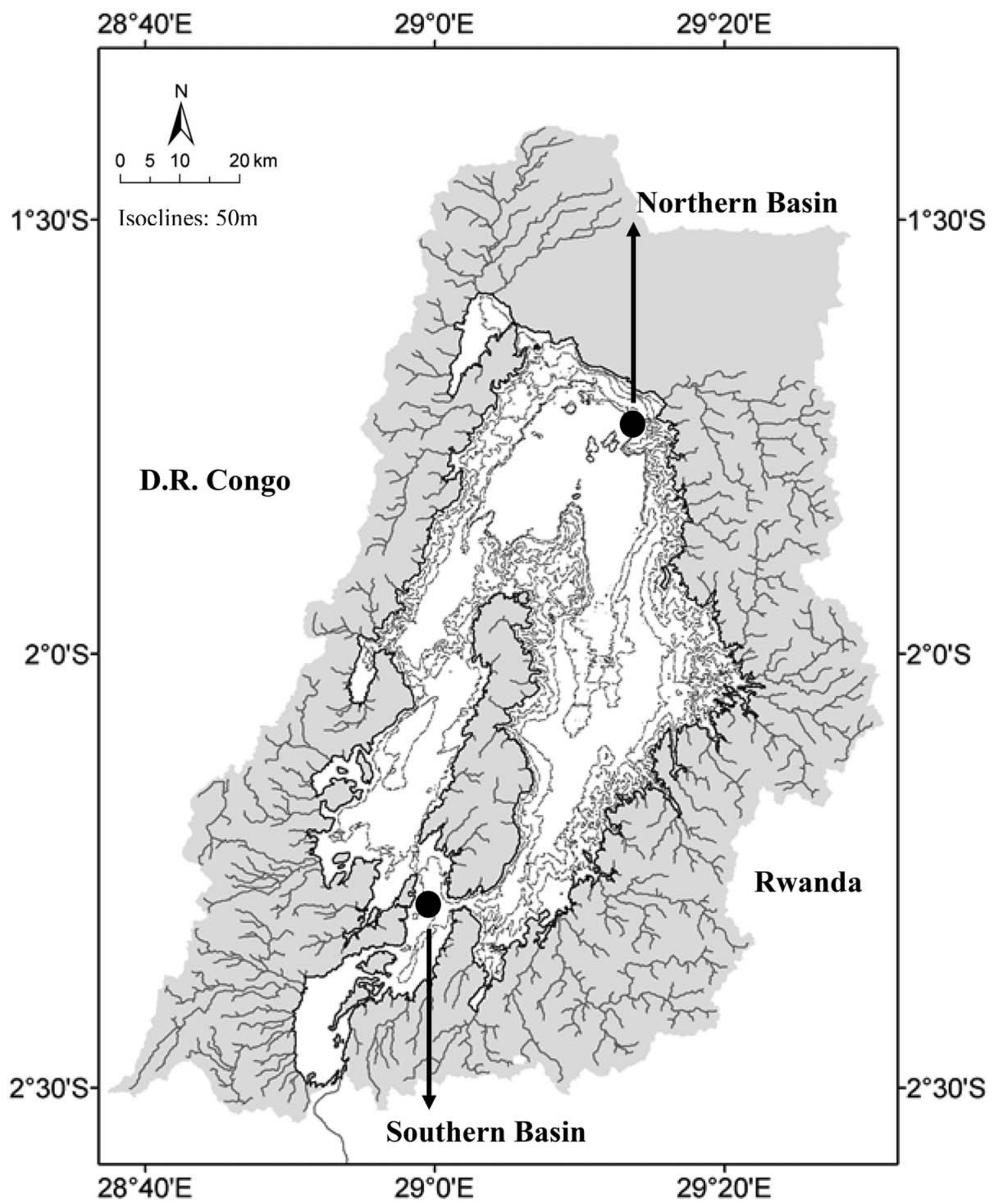

Fig. 1. Map of Lake Kivu, showing sampling sites in the Northern and Southern Basins.

screw caps. Before the injection of ${ }^{15} \mathrm{~N}$-labeled solutions, a $12 \mathrm{~h}$ pre-incubation period in dark and at ambient temperature $\left(\sim 25^{\circ} \mathrm{C}\right)$ was observed in order to allow the consumption of oxygen inadvertently introduced to the bottles during sampling.

$\mathrm{N}$ stable isotope labeling experiments were based on Thamdrup and Dalsgaard (2002). Denitrification, anammox, and DNRA were determined by amending water with ${ }^{15} \mathrm{NO}_{3}^{-}$ to a final concentration of $5 \mu \mathrm{mol} \mathrm{L} \mathrm{L}^{-1}$. During the rainy season, anammox was also determined by amendment with ${ }^{15} \mathrm{NH}_{4}^{+}$to a final concentration of $5 \mu \mathrm{mol} \mathrm{L}{ }^{-1}$. Amendments were made by injecting stock label solutions (concentration of $2.5 \mathrm{mmol} \mathrm{L}^{-1}$ ) through the septa of the amber glass vials. Six $12 \mathrm{~mL}$ vials (Labco Exetainer) were then filled with a 
tube from the bottom of each of the duplicate bottles, and placed in the dark in an incubator at ambient temperature $\left(\sim 25^{\circ} \mathrm{C}\right)$, which was close to the in situ temperature $\left(\sim 24^{\circ} \mathrm{C}\right)$. Exetainers vials were overfilled to avoid exposure to oxygen. Microbial activity in two Exetainers was immedi-

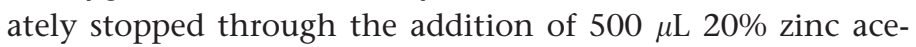
tate (ZnAc). A time course was established by arresting two further Exetainers at 6 h, 12 h, 18 h, 24 h, and 48 h. In order to test the effect of $\mathrm{HS}^{-}$on $\mathrm{N}$ transformations, experiments were conducted with the supplementary addition of $\mathrm{HS}^{-}$to amber bottles with ${ }^{15} \mathrm{NO}_{3}^{-}$(for final concentration of 10 $\mu$ mol $\mathrm{L}^{-1}$ during the rainy season only). In the Northern Basin, during the rainy season, ${ }^{15} \mathrm{NO}_{3}^{-}$enrichment experiments were also conducted at $55 \mathrm{~m}, 60 \mathrm{~m}$, and $65 \mathrm{~m}$, with ${ }^{15} \mathrm{NO}_{3}^{-}$final concentrations of $0.5 \mu \mathrm{mol} \mathrm{L}{ }^{-1}, 1 \mu \mathrm{mol} \mathrm{L}{ }^{-1}, 2$ $\mu \mathrm{mol} \mathrm{L}{ }^{-1}, 5 \mu \mathrm{mol} \mathrm{L}{ }^{-1}$, and $10 \mu \mathrm{mol} \mathrm{L}{ }^{-1}$. These experiments were conducted on water collected $3 \mathrm{~d}$ after the other labeling experiments.

${ }^{29} \mathrm{~N}_{2}$ and ${ }^{30} \mathrm{~N}_{2}$ concentrations in the Exetainer vials were measured with a gas source isotope ratio mass spectrometer (delta $\mathrm{V}$ plus, ThermoScientific) after creating a $1 \mathrm{~mL}$ helium headspace (volume injected in the mass spectrometer: 50 $\mu \mathrm{L}$ ). Denitrification and anammox rates (detection limits of $2.7 \mathrm{nmol} \mathrm{L}^{-1} \mathrm{~h}^{-1}$ and $0.07 \mathrm{nmol} \mathrm{L} \mathrm{L}^{-1} \mathrm{~h}^{-1}$, respectively) in the incubations with ${ }^{15} \mathrm{NO}_{3}^{-}$were calculated according to Eqs. 1 and 2, and anammox rates in the incubation with ${ }^{15} \mathrm{NH}_{4}^{+}$were calculated according to Eq. 3 (Thamdrup and Dalsgaard 2002; Thamdrup et al. 2006):

$$
\begin{array}{r}
\mathrm{N}_{2 \text { denitrification 15NO3 }}={ }^{15} \mathrm{~N}^{15} \mathrm{~N}_{\text {excess }} *\left(\mathrm{~F}_{\mathrm{NO} 3}\right)^{-2} \\
\mathrm{~N}_{2 \text { anammox 15NO3 }}=\left(\mathrm{F}_{\mathrm{NO} 3}\right)^{-1} *\left({ }^{14} \mathrm{~N}^{15} \mathrm{~N}_{\text {excess }}+2\right. \\
\left.*\left(1-\left(\mathrm{F}_{\mathrm{NO} 3}\right)^{-1}\right) *{ }^{15} \mathrm{~N}^{15} \mathrm{~N}_{\text {excess }}\right) \\
\mathrm{N}_{2 \text { anammox 15NH4 }}={ }^{15} \mathrm{~N}^{14} \mathrm{~N}_{\text {excess }} *\left(\mathrm{~F}_{\mathrm{NH} 4}\right)^{-1}
\end{array}
$$

where $\mathrm{N}_{2}$ denitrification $15 \mathrm{NO}$ and $\mathrm{N}_{2}$ anammox $15 \mathrm{NO} 3$ are the production of $\mathrm{N}_{2}$ by denitrification and anammox, respectively, in the incubations with ${ }^{15} \mathrm{NO}_{3}^{-}$and $\mathrm{N}_{2}$ anammox ${ }_{15 \mathrm{NH} 4}$ is the production of $\mathrm{N}_{2}$ by anammox in the incubations with ${ }^{15} \mathrm{NH}_{4}^{+} \cdot{ }^{15} \mathrm{~N}^{15} \mathrm{~N}_{\text {excess }}$ is the production of excess ${ }^{15} \mathrm{~N}^{15} \mathrm{~N}$, ${ }^{14} \mathrm{~N}^{15} \mathrm{~N}_{\text {excess }}$ is the production of excess ${ }^{14} \mathrm{~N}^{15} \mathrm{~N}, \mathrm{~F}_{\mathrm{NO}}$ is the fraction of ${ }^{15} \mathrm{NO}_{3}^{-}$in the $\mathrm{NO}_{\mathrm{x}}$ pool and $\mathrm{F}_{\mathrm{NH} 4}$ is the fraction of ${ }^{15} \mathrm{NH}_{4}^{+}$in the $\mathrm{NH}_{4}^{+}$pool. ${ }^{15} \mathrm{~N}^{15} \mathrm{~N}$ and ${ }^{14} \mathrm{~N}^{15} \mathrm{~N}$ excess is the excess relative to mass 30 and 29 , respectively, in the time zero gas samples.

${ }^{29} \mathrm{~N}_{2}$ and ${ }^{30} \mathrm{~N}_{2}$ concentrations from $\mathrm{N}_{2} \mathrm{O}$ were also measured in the incubations with the mass spectrometer. $\mathrm{N}_{2} \mathrm{O}$ peaks appeared after their respective $\mathrm{N}_{2}$ peaks. Total $\mathrm{N}_{2} \mathrm{O}$ production rates in the incubations were calculated by the sum of the ${ }^{15} \mathrm{~N}^{15} \mathrm{~N}_{\text {excess }}$ and the ${ }^{14} \mathrm{~N}^{15} \mathrm{~N}_{\text {excess. }}$.

DNRA was only measured during the rainy season and was determined as the accumulation of ${ }^{15} \mathrm{~N}_{\text {excess }}$ from $\mathrm{NO}_{3}^{-}$ into the $\mathrm{NH}_{4}^{+}$pool, in the same incubations than for denitrification and anammox measurements. When denitrification and anammox measurements were completed, the water samples were flushed with helium in order to evacuate all the $\mathrm{N}_{2}$ present. Measurements of ${ }^{15} \mathrm{~N}_{-} \mathrm{NH}_{4}^{+}$were conducted by converting $\mathrm{NH}_{4}^{+}$to $\mathrm{N}_{2}$ following oxidation by hypobromite, as previously described by Knowles and Blackburn (1993). $\mathrm{N}_{2}$ was then analyzed as described above.

$$
\mathrm{NH}_{4}{ }^{+} \text {DNRA }={ }^{15} \mathrm{NH}_{4}{ }^{+} \text {excess } *\left(\mathrm{~F}_{\mathrm{NO} 3}\right)
$$

where ${ }^{15} \mathrm{NH}_{4}{ }^{+}$excess is the production of excess ${ }^{15} \mathrm{NH}_{4}{ }^{+}$in the $\mathrm{NH}_{4}^{+}$pool.

While injecting ZnAc solution to stop the incubations of the Exetainers, the excess water was collected in $2 \mathrm{~mL}$ Eppendorf vials, and stored frozen, to determine the evolution of the $\mathrm{NO}_{\mathrm{x}}$ concentrations through time. $\mathrm{NO}_{\mathrm{x}}$ were then analyzed by chemiluminescence, after reduction with vanadium chloride $\left(\mathrm{VCl}_{3}\right)$, with an $\mathrm{NO}_{2}^{-}, \mathrm{NO}_{3}^{-}$, and $\mathrm{NO}_{\mathrm{x}}$ analyzer (Thermo Environmental Instruments), according to the method described by Braman and Hendrix (1989) (detection limit: $0.03 \mu \mathrm{mol} \mathrm{L}^{-1}$ ).

\section{Water-column chemical analyses}

Samples for determination of vertical profiles of $\mathrm{NO}_{\mathrm{x}}$ concentrations were collected in 2 mL-Eppendorf vials, stored frozen and analyzed as described above.

Samples for the determination of $\mathrm{NH}_{4}^{+}, \mathrm{NO}_{3}^{-}$, and $\mathrm{NO}_{2}^{-}$ concentrations in vertical profiles were collected in $50 \mathrm{~mL}$ plastic vials after being filtered through a $0.22 \mu \mathrm{m}$ syringe filter. $200 \mu \mathrm{L}$ of $\mathrm{H}_{2} \mathrm{SO}_{4}(5 \mathrm{~N})$ were added to each vial for preservation, and samples were stored frozen. $\mathrm{NH}_{4}^{+}$and $\mathrm{NO}_{2}^{-}$ concentrations were quantified by spectrophotometry, using a 5-cm light path on a spectrophotometer Thermo Spectronic Genesys 10vis, according to the dichloroisocyanuratesalicylate-nitroprussiate colorimetric method (Westwood 1981) and the sulfanilamide coloration method (APHA 1998), respectively. $\mathrm{NO}_{3}^{-}$concentrations were determined after vanadium reduction to $\mathrm{NO}_{2}^{-}$and quantified with a Multiskan Ascent Thermo Scientific multi-plates reader (APHA 1998; Miranda et al. 2001). The detection limits for these methods were $0.3 \mu \mathrm{mol} \mathrm{L}{ }^{-1}, 0.03 \mu \mathrm{mol} \mathrm{L}^{-1}$, and $0.15 \mu \mathrm{mol}$ $\mathrm{L}^{-1}$, for $\mathrm{NH}_{4}^{+}, \mathrm{NO}_{2}^{-}$, and $\mathrm{NO}_{3}^{-}$, respectively.

Samples for $\mathrm{H}_{2} \mathrm{~S}$ concentrations were collected directly from the Niskin-type bottle in $60 \mathrm{~mL}$ plastic syringes. Water was filtered through a $0.22 \mu \mathrm{m}$ encapsulated syringe filter in $50 \mathrm{~mL}$ plastic vials, without contact with the atmosphere, and was rapidly preserved with $200 \mu \mathrm{L}$ of $20 \%$ ZnAc. Samples were stored frozen. $\mathrm{H}_{2} \mathrm{~S}$ concentrations were quantified using a 1-cm light path on a spectrophotometer, according to the method described by Cline (1969) (detection limit: 0.25 $\left.\mu \mathrm{mol} \mathrm{L}^{-1}\right)$. Samples for $\mathrm{SO}_{4}^{2-}$ concentrations were filtered through a $0.22 \mu \mathrm{m}$ syringe filter and collected in $5 \mathrm{~mL}$ cryotube. Samples were preserved with $20 \mu \mathrm{L}$ of $20 \% \mathrm{ZnAc}$ and were stored frozen. $\mathrm{SO}_{4}^{2-}$ concentrations were determined by ion chromatography (Dionex ICS-1500, with an autosampler 

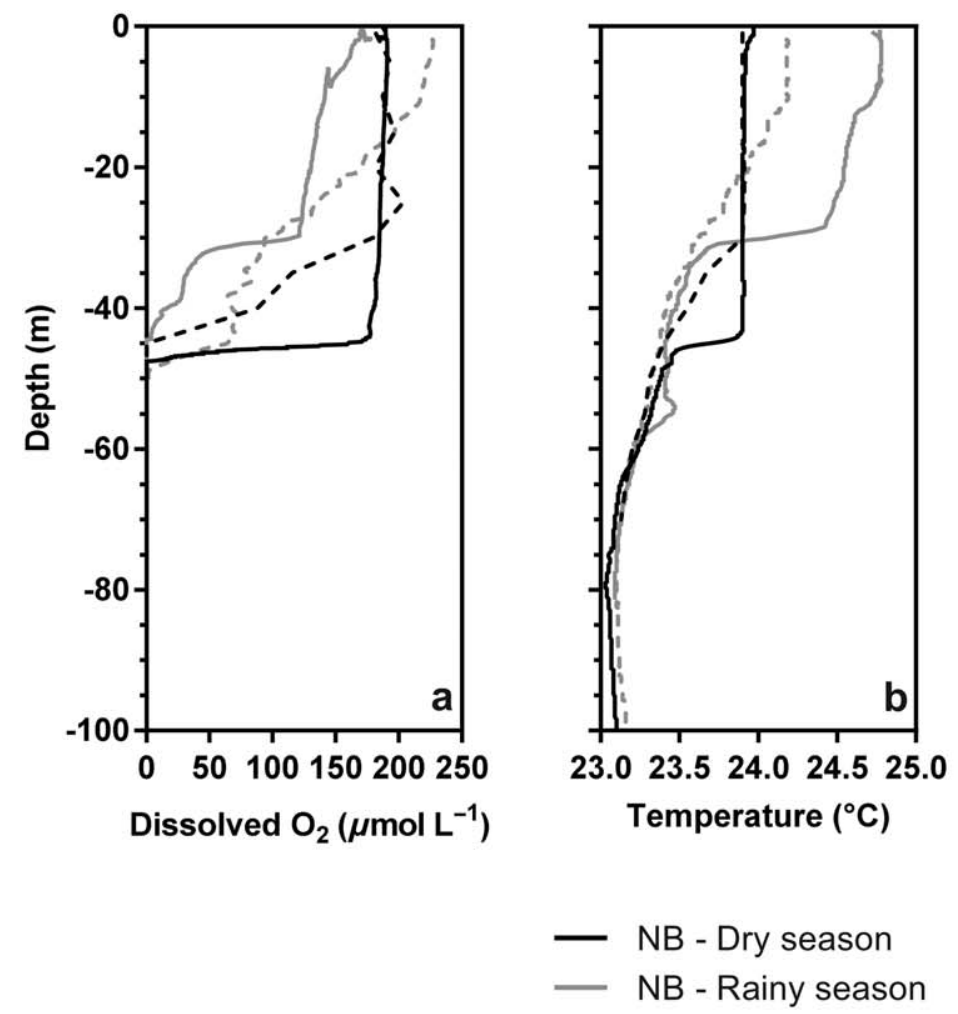
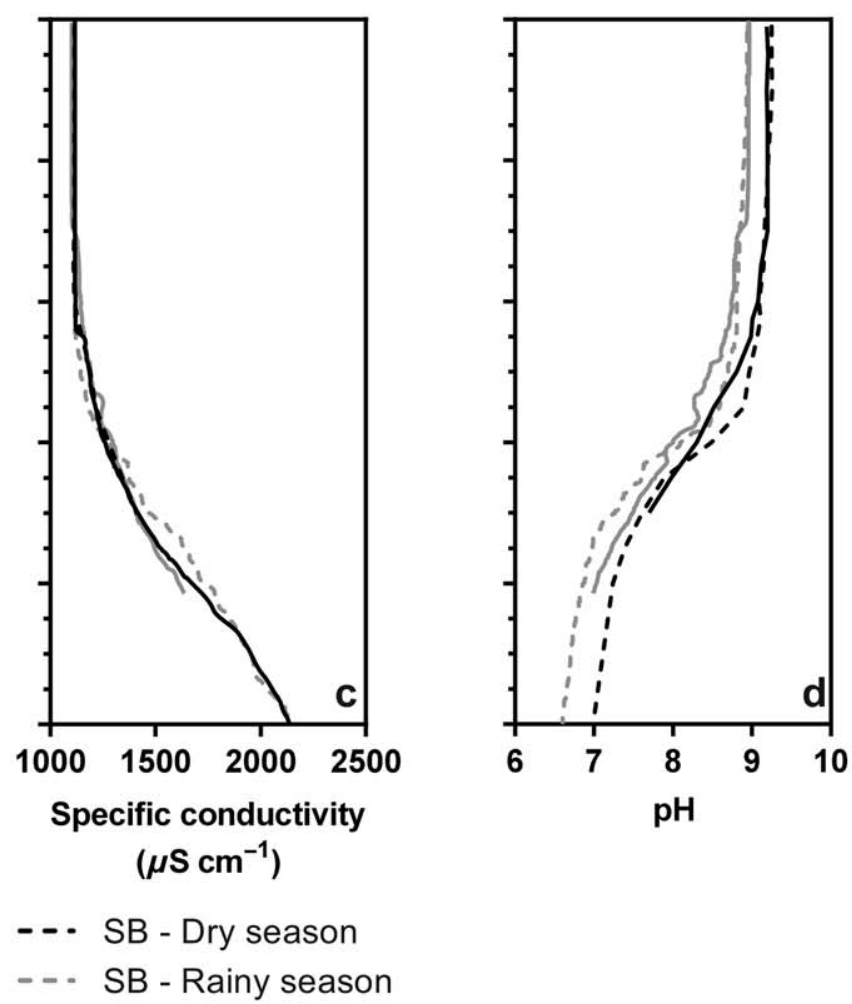

Fig. 2. Physico-chemical parameters (a: dissolved oxygen $\left(\mu \mathrm{mol} \mathrm{L}^{-1}\right)$; b: temperature $\left({ }^{\circ} \mathrm{C}\right)$; c: specific conductivity $\left(\mu \mathrm{S} \mathrm{cm}^{-1}\right)$; $\mathrm{d}$ : $\left.\mathrm{pH}\right)$ in the Northern Basin (NB; full lines) and Southern Basin (SB; dashed lines), during the dry season (June 2011; black lines) and rainy season (February 2012; grey lines).

Dionex AS50, a guard column Dionex AG22 and an analytical column Dionex IonPac AS22; detection limit: 0.5 $\mu \mathrm{mol} \mathrm{L}{ }^{-1}$ ).

Samples for determination of $\mathrm{N}_{2} \mathrm{O}$ concentrations in vertical profiles were collected in $50 \mathrm{~mL}$ borosilicate serum bottles from the Niskin bottle with a tube, left to overflow, poisoned with $100 \mu \mathrm{L}$ of saturated $\mathrm{HgCl}_{2}$ and sealed with butyl stoppers and aluminum caps. Concentration of $\mathrm{N}_{2} \mathrm{O}$ was determined via the headspace equilibration technique and measured by gas chromatography as described by Borges et al. (2015).

\section{Results and discussion}

Physico-chemical parameters and Lake Kivu vertical structure description

Lake Kivu is a large $\left(2370 \mathrm{~km}^{2}\right)$ and deep (maximum depth of $485 \mathrm{~m}$ ) meromictic lake with permanent anoxic waters below $70 \mathrm{~m}$, but with fluctuations in the depth of the oxycline between the dry and the rainy season (oxygen is mixed to deeper waters in the dry season). It can be divided into a Southern Basin that is smaller and shallower (maximum depth of $180 \mathrm{~m}$ ) than the Northern Basin (also called main basin, maximum depth of $485 \mathrm{~m}$ ) and both are connected at a depth of $130 \mathrm{~m}$ (Descy et al. 2012). Due to its smaller size, the Southern Basin is less influenced by wind driven mixing. Episodic fluctuations of the stratification are thought to be less frequent in the Southern basin due to sheltering by the surrounding hills (Darchambeau et al. 2014). During our study, differences in the vertical structure of the water column between the Northern and Southern basins were observed (Fig. 2). In the Northern Basin, during the dry season, the water column was anoxic below $47.5 \mathrm{~m}$, while it was anoxic below $45.0 \mathrm{~m}$ during the rainy season. In the Southern Basin, the water column was anoxic below $45.0 \mathrm{~m}$ during the dry season and below $50.0 \mathrm{~m}$ during the rainy season. Primary thermoclines in the Northern Basin strongly differed between seasons and were coincident with the oxycline. In the Southern Basin, the difference between the thermocline between seasons was less notable.

$\mathrm{NH}_{4}^{+}$concentrations reflected the stratification in both basins and were low $\left(<2 \mu \mathrm{mol} \mathrm{\textrm {L } ^ { - 1 } )}\right.$ in the oxic waters, increasing to concentrations up to $90 \mu \mathrm{mol} \mathrm{L^{-1 }}$ and 152 $\mu \mathrm{mol} \mathrm{\textrm {L } ^ { - 1 }}$ at $70 \mathrm{~m}$, in the Northern and Southern Basins, respectively (Fig. 3). The accumulation of $\mathrm{NH}_{4}^{+}$in anoxic waters reflects ammonification during the degradation of the organic matter and the absence of nitrification in the absence of $\mathrm{O}_{2}$. $\mathrm{HS}^{-}$concentrations were also higher in anoxic waters, while $\mathrm{SO}_{4}^{2-}$ concentrations were relatively high (100$200 \mu \mathrm{mol} \mathrm{L}^{-1}$ ) in oxic waters and started to decrease in the top part of the anoxic waters, where $\mathrm{HS}^{-}$increased. 


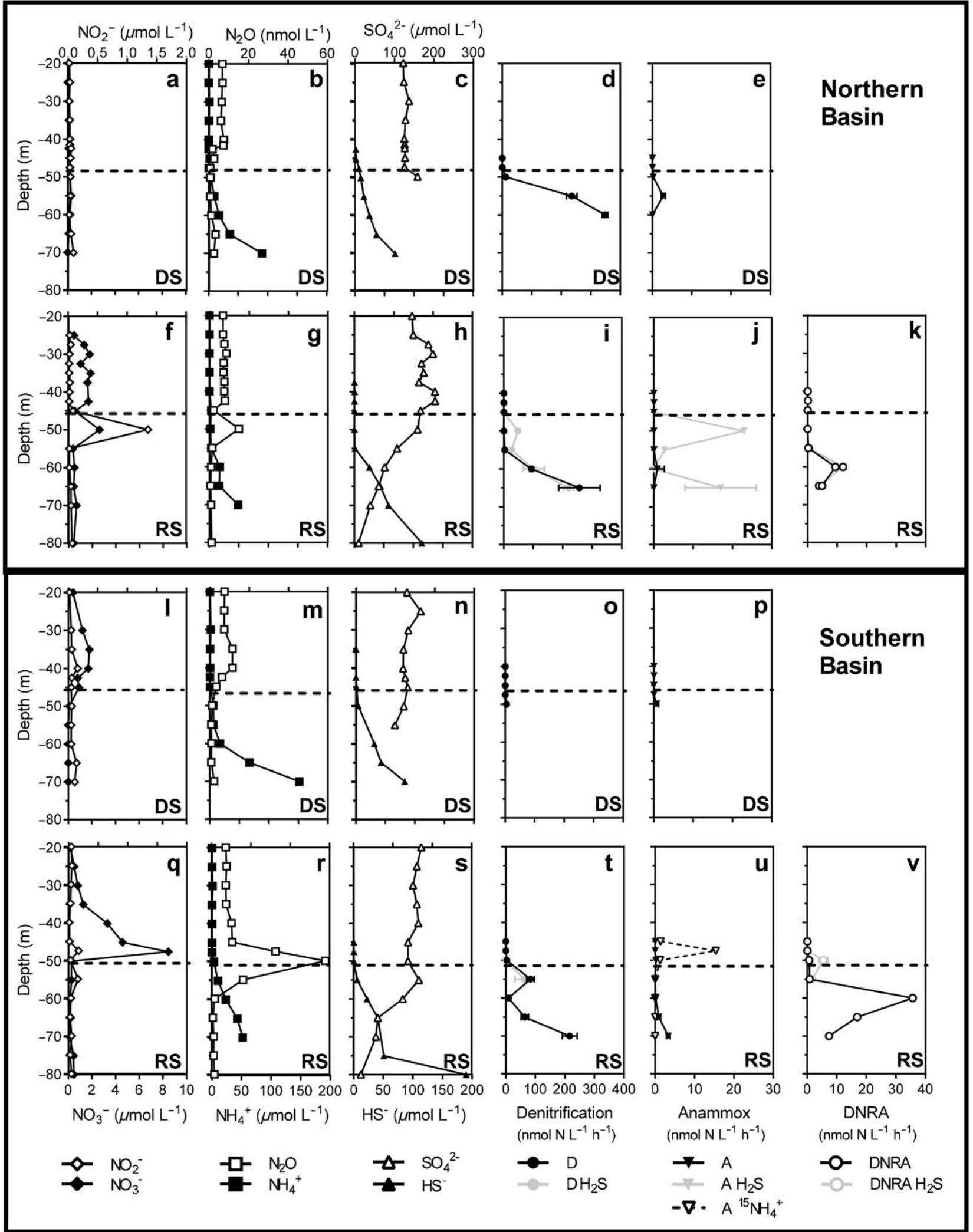

Fig. 3. Vertical profiles of $\mathrm{NO}_{3}^{-}$and $\mathrm{NO}_{2}^{-}\left(\mathrm{a}, \mathrm{f}, \mathrm{l}, \mathrm{q} ; \mu \mathrm{mol} \mathrm{\textrm {L } ^ { - 1 } ) , \mathrm { N } _ { 2 } \mathrm { O } \text { and } \mathrm { NH } _ { 4 } ^ { + } ( \mathrm { b } , \mathrm { g } , \mathrm { m } , \mathrm { r } ; \mathrm { nmol } \mathrm { L }} \mathrm{L}^{-1}\right.$ and $\mu$ mol $\mathrm{L}^{-1}$, respectively), $\mathrm{SO}_{4}^{2-}$ and $\mathrm{HS}^{-}(\mathrm{c}, \mathrm{h}$,

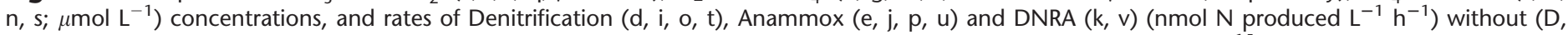
$A$, and DNRA, respectively) and with ( $\mathrm{D} \mathrm{H}_{2} \mathrm{~S}, \mathrm{~A} \mathrm{H}_{2} \mathrm{~S}$, and DNRA $\mathrm{H}_{2} \mathrm{~S}$, respectively) $\mathrm{H}_{2} \mathrm{~S}$ added in the incubations with ${ }^{15} \mathrm{NO}_{3}^{-}$added, during both seasons (RS: Rainy season; DS: Dry season) and in both stations (Northern Basin: a-k; Southern Basin: I-v), and Anammox rates in the incubations with ${ }^{15} \mathrm{NH}_{4}^{+}$added $\left(\mathrm{A}^{15} \mathrm{NH}_{4}^{+} ; \mathrm{u}\right)$ in rainy season. 
$\mathrm{NO}_{2}^{-}$and $\mathrm{NO}_{3}^{-}$concentrations were low throughout most of the water column (Fig. 3), for both seasons and both stations, but accumulation up to $1.5 \mu \mathrm{mol} \mathrm{L}{ }^{-1}$ (in the Northern Basin) and $8.0 \mu \mathrm{mol} \mathrm{L}{ }^{-1}$ (in the Southern Basin), respectively, was observed during the rainy season in proximity to the boundary between oxic and anoxic waters. $\mathrm{NO}_{3}^{-}$and $\mathrm{NO}_{2}^{-}$accumulation generally co-occurred with peaks in $\mathrm{N}_{2} \mathrm{O}$ concentrations $\left(15 \mathrm{nmol} \mathrm{L}{ }^{-1}\right.$ in the Northern Basin, and 58 nmol L $\mathrm{L}^{-1}$ in the Southern Basin). Low oxygen concentrations within these depth intervals suggest redox conditions favorable both to denitrification and to high $\mathrm{N}_{2} \mathrm{O}$ yields (Codispoti et al. 1992). During the dry season, $\mathrm{N}_{2} \mathrm{O}$ concentrations were higher in oxic waters (around $10 \mathrm{nmol} \mathrm{L} \mathrm{L}^{-1}$ ) than in anoxic waters (below $5 \mathrm{nmol} \mathrm{L}^{-1}$ ), at both stations. $\mathrm{N}_{2} \mathrm{O}$ concentrations were near the atmospheric equilibrium in superficial oxic waters (Supporting Information Table S1), while the water column was clearly undersaturated in deep anoxic waters, and oversaturated near the oxic-anoxic interface.

\section{Co-occurrence of denitrification, anammox, and DNRA in the water column of Lake Kivu}

Results of time course incubations (29 excess and $30_{\text {excess }}$ production) are reported in Supporting Information Fig. S1. Irrespective of seasons and stations, the increase of 29 excess and $30_{\text {excess }}$ tended to be low at the beginning of the incubation, then strongly increased, and finally tended to stabilize at the end of the incubation. The initial time lag observed before the production of $\mathrm{N}_{2}$ could be explained by the time required for the community to recover from the perturbation of the sampling. The plateau observed at the end of the incubations could be due to a bacterial community saturation or substrates limitation $\left(\mathrm{NO}_{3}^{-}\right.$or organic matter).

All the rates reported are statistically significant $(p<0.05)$. Rates reported in this section should be considered as potential rates due to the fact that the addition of the ${ }^{15} \mathrm{~N}$ labeled compounds increased substrate concentrations relative to their in situ values. Rates and pathways differed between seasons and stations (Fig. 3). Denitrification rates were higher in the Northern Basin than in the Southern Basin for both seasons. The maximum denitrification rate of $348 \mathrm{nmol} \mathrm{N}$ produced $\mathrm{L}^{-1} \mathrm{~h}^{-1}$ was observed at $60 \mathrm{~m}$ depth during the dry season. In the Southern Basin, the maximum denitrification rate was $216 \mathrm{nmol} \mathrm{N}$ produced $\mathrm{L}^{-1} \mathrm{~h}^{-1}$ and was observed at $70 \mathrm{~m}$ during the rainy season. During the dry season, almost no denitrification was observed in the Southern Basin, probably due to shallow sampling (denitrification seemed to start at $50 \mathrm{~m}$ depth, and was maybe present deeper). In contrast to denitrification, rates of anammox tended to be higher in the Southern Basin. The maximum anammox rate of $3.3 \mathrm{nmol} \mathrm{N}$ produced $\mathrm{L}^{-1} \mathrm{~h}^{-1}$ was observed in the Southern Basin at $70 \mathrm{~m}$ during the rainy season. The maximum anammox rate was less than $1 \%$ of the maximum denitrification rate, suggesting it played a small role in $\mathrm{N}_{2}$ production in Lake Kivu. DNRA was also observed in the water column of Lake Kivu during our study. In contrast to denitrification, but like anammox, rates of DNRA were higher in the Southern Basin, with a maximum rate of 36 nmol $\mathrm{N}$ produced $\mathrm{L}^{-1} \mathrm{~h}^{-1}$ observed at $60 \mathrm{~m}$. In the Northern Basin, the maximum rate of DNRA was $9 \mathrm{nmol} \mathrm{N}$ produced $\mathrm{L}^{-1} \mathrm{~h}^{-1}$ at $60 \mathrm{~m}$.

Schubert et al. (2006) used the same method to quantify denitrification and anammox in the water column of Lake Tanganyika. The vertical structure of Lake Tanganyika water column shares characteristics with Lake Kivu water column: anoxic waters rich in $\mathrm{NH}_{4}^{+}$, oxic surface waters depleted in nutrients, $\mathrm{NO}_{3}^{-}$accumulation $\left(\sim 10 \mu \mathrm{mol} \mathrm{L} \mathrm{L}^{-1}\right)$ near the oxic-anoxic interface and very low $\mathrm{NO}_{2}^{-}$concentrations. Schubert et al. (2006) reported maximum denitrification rates of $200 \mathrm{nmol} \mathrm{N}$ produced $\mathrm{L}^{-1} \mathrm{~h}^{-1}$ - the same magnitude as the rates observed in Lake Kivu. In Lake Rassnitzer, Hamersley et al. (2009) measured maximum denitrification rates of only $6 \mathrm{nmol} \mathrm{N}$ produced $\mathrm{L}^{-1} \mathrm{~h}^{-1}$. These two studies also measured anammox rates from ${ }^{15} \mathrm{NO}_{3}^{-}$-labelling experiments, and obtained rates of 20 and $1.4 \mathrm{nmol} \mathrm{N}$ produced $\mathrm{L}^{-1} \mathrm{~h}^{-1}$ in Lake Tanganyika and Rassnitzer, respectively. In marine environments, denitrification was estimated to 0-216 nmol $\mathrm{N}$ produced $\mathrm{L}^{-1} \mathrm{~h}^{-1}$ (e.g., Brettar and Rheinheimer 1991; Thamdrup et al. 2006; Dalsgaard et al. 2013). If we compare in terms of relative contribution of anammox to $\mathrm{N}_{2}$ (Table 1), we estimated it to be potentially up to $13 \%$ in Lake Kivu, exactly like in Lake Tanganyika (Schubert et al. 2006), while it was estimated to up to 50\% in Lake Rassnitzer (Hamersley et al. 2009). In the anoxic water column of Golfo Duce, anammox accounted for 19-35\% in the formation of $\mathrm{N}_{2}$ (Dalsgaard et al. 2003). In Lake Kivu, anammox was not measurable in the main basin (Northern Basin), and can be thus considered as of little importance in the water column of Lake Kivu. However, we must note that our anammox rates could be underestimated, since they were measured indirectly from the addition of ${ }^{15} \mathrm{NO}_{3}^{-}$, instead of addition of ${ }^{15} \mathrm{NO}_{2}^{-}$and ${ }^{15} \mathrm{NH}_{4}^{+}$. As denitrification can also produce ${ }^{29} \mathrm{~N}_{2}$, we firstly considered that ${ }^{29} \mathrm{~N}_{2}$ produced was due to denitrification. When ${ }^{29} \mathrm{~N}_{2}$ production was too high to be explained by denitrification only, we attributed it to anammox. Moreover, it is still unclear if anammox bacteria can use $\mathrm{NO}_{3}^{-}$to oxidize $\mathrm{NH}_{4}^{+}$. The study of Kartal et al. (2007) showed that anammox bacteria were capable to reduce $\mathrm{NO}_{3}^{-}$in $\mathrm{NO}_{2}^{-}$, but at a rate $10 \%$ lower than the anammox rate with $\mathrm{NO}_{2}^{-}$. The low anammox rates observed during this study can thus also be due to the need to firstly reduce ${ }^{15} \mathrm{NO}_{3}^{-}$to ${ }^{15} \mathrm{NO}_{2}^{-}$, which seems to be an unfavorable process for anammox bacteria.

The differences in denitrification and anammox rates between the different environments can be attributed to the different bacterial communities and environment characteristics, such as substrate availability, physico-chemical parameters ( $\mathrm{pH}$, oxygen, salinity, temperature), and the presence 
Table 1. Contribution (\%) of denitrification and anammox in the formation of $\mathrm{N}_{2}$, in both basins and during both campaigns, with and without $\mathrm{H}_{2} \mathrm{~S}$ added.

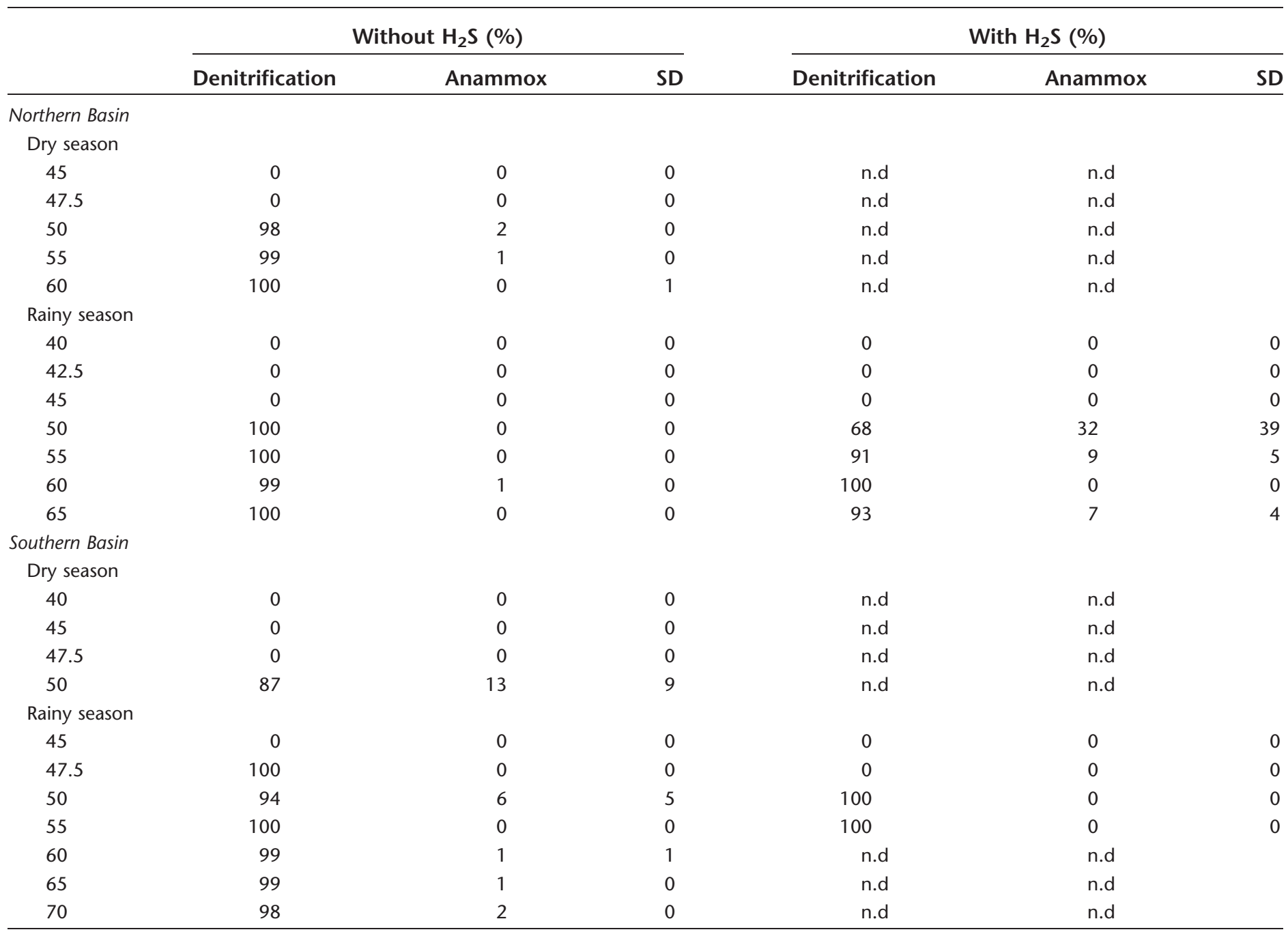

n.d., not determined; SD, standard deviation.

of inhibitors (e.g., high concentrations of $\mathrm{NH}_{4}^{+}, \mathrm{NO}_{2}^{-}$, organic matter) (Jin et al. 2012). For example, temperature in Lake Rassnitzer was around $5^{\circ} \mathrm{C}$ at depths sampled during the study of Hamersley et al. (2009), while it was around $23^{\circ} \mathrm{C}$ in Lake Kivu, strongly influencing anammox and denitrification processes (Saad and Conrad 1993; Van Hulle et al. 2010; Dong et al. 2011). Also, the abundance and diversity of bacterial communities play an important role. Currently, all anammox bacteria identified belong to the order Planctomycetales (Strous et al. 1999). The study of Inceoğlu et al. $(2015 b)$ focused on the identification of bacterial and archaeal communities in the water column of Lake Kivu, at the same stations and during the same field campaigns. These authors showed that Planctomycetes were present in the water column, but not well represented $(<1 \%)$, in agreement with low anammox rates we observed during this study. On the contrary, in Lake Tanganyika, anammox bacteria seemed to be better represented (up to 1.4\%) and overall, were highly active (Schubert et al. 2006), which may explain higher anammox rates observed. High denitrification rates observed in Lake Kivu can also be linked to the abundance of the denitrifying bacterial community. Indeed, Inceoğlu et al. (2015b) also revealed the presence of a diversified community of Proteobacteria, among which Betaproteobacteria. Numerous nitrogen cycle-related bacteria belong to this class, including well-known denitrifiers, such as Thiobacillus sp. and Denitratisoma sp. (Claus and Kutzner 1985; Tiedje 1994; Ghosh and Dam 2009). In addition to the presence of these bacteria, İnceoğlu et al. (2015a) also put in evidence their activity by the identification of specific genes. They thus showed the presence of functional genes involved in denitrification, strongly supporting the occurrence of 

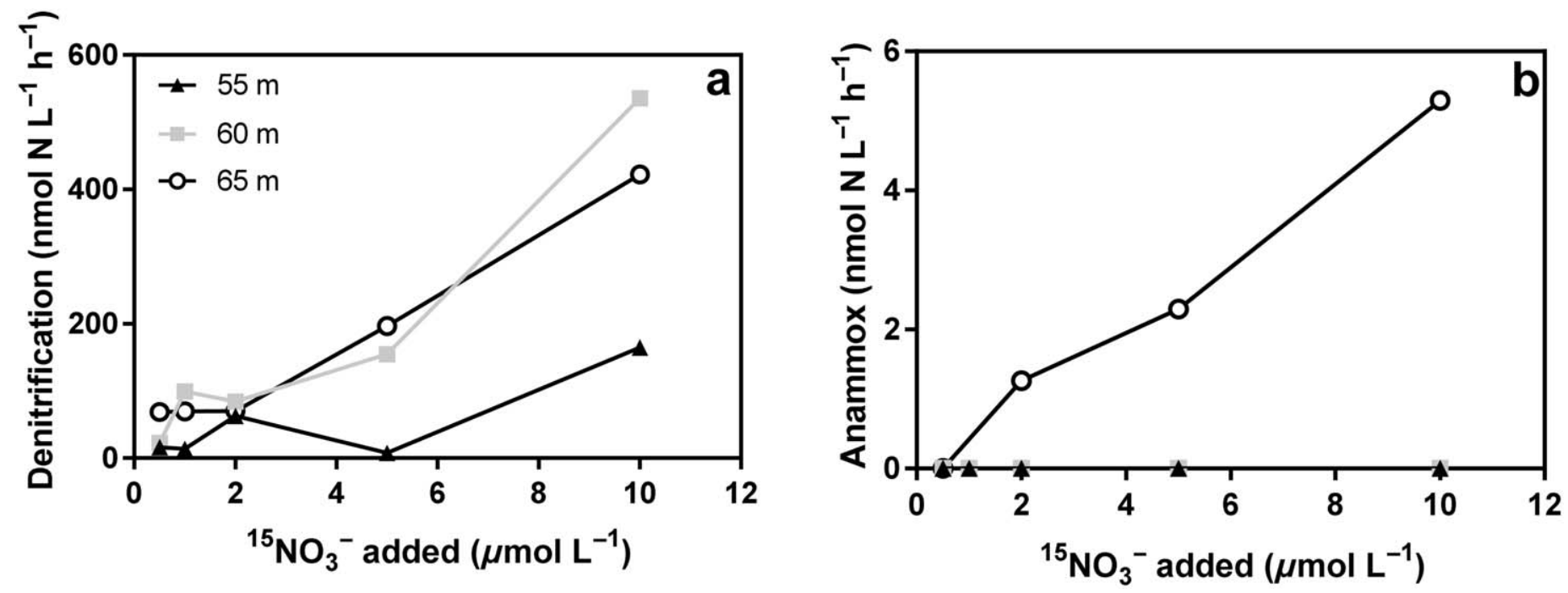

Fig. 4. Potential denitrification (a) and anammox (b) rates (nmol $\mathrm{N}$ produced $\mathrm{L}^{-1} \mathrm{~h}^{-1}$ ) with different ${ }^{15} \mathrm{NO}_{3}^{-}$concentrations added $\left(0.5 \mu\right.$ mol $\mathrm{L}^{-1}, 1$ $\mu \mathrm{mol} \mathrm{L}-1,2 \mu \mathrm{mol} \mathrm{L}^{-1}, 5 \mu \mathrm{mol} \mathrm{L}^{-1}$, and $10 \mu \mathrm{mol} \mathrm{L}^{-1}$ ), in the Northern Basin, during the rainy season, at the depths of 55 (black triangles), 60 (grey squares), and $65 \mathrm{~m}$ (white circles). Experiments were conducted during rainy season only (08 February 2012).

denitrification in the water column of Lake Kivu. Also, the water column of Lake Kivu seems to be a favorable environment for DNRA, since Epsilonproteobacteria, Deltaproteobacteria and Gammaproteobacteria, among which we can find bacteria capable of DNRA, such as Wolinella sp., Desulfovibrio sp., Geobacter sp., or Vibrio sp. (e.g., Bokranz et al. 1983; Dalsgaard and Bak 1994; Strohm et al. 2007) were well represented (İnceoğlu et al. 2015b).

Bacterial diversity data thus confirm that denitrification and DNRA naturally occur in the water column of Lake Kivu. The conditions for the occurrence of these processes are encountered during the rainy season, since non negligible $\mathrm{NO}_{\mathrm{x}}$ concentrations were observed. Moreover, in the Northern Basin, the location of the $\mathrm{N}_{2} \mathrm{O}$ peak in the anoxic part of the water column suggests that $\mathrm{N}_{2} \mathrm{O}$ could have been produced through denitrification. On the contrary, the water column of Lake Kivu first might seem to be unfavorable for anammox, since Planctomycetes were seldom observed (İnceoğlu et al. 2015b). As shown by Fig. 4, the scales of the rates measured are linear in our range of $\mathrm{NO}_{3}^{-}$concentrations. We thus calculated natural rates $\left({ }^{14} \mathrm{~N}^{14} \mathrm{~N}\right)$ in our incubations with ${ }^{15} \mathrm{NO}_{3}^{-}$added according to following equations:

Natural $\mathrm{N}_{2}$ denitrification $=$ Potential $\mathrm{N}_{2}$ denitrification $*\left(1-\mathrm{F}_{\mathrm{NO} 3}\right)$

$$
\begin{aligned}
& \text { Natural } \mathrm{N}_{2} \text { anammox }=\text { Potential } \mathrm{N}_{2} \text { anammox } *\left(1-\mathrm{F}_{\mathrm{NO} 3}\right) \\
& \text { Natural } \mathrm{NH}_{4}{ }^{+} \text {DNRA }=\text { Potential } \mathrm{NH}_{4}{ }^{+} \text {DNRA } *\left(1-\mathrm{F}_{\mathrm{NO} 3}\right)
\end{aligned}
$$

Supporting Information Figure S2 reports natural rates measured in our incubations, i.e., rates recomputed without substrates added. Denitrification was naturally present in the water column of Lake Kivu, in particular during the rainy season, where a maximum rate of $93 \mathrm{nmol} N$ produced $\mathrm{L}^{-1}$ $\mathrm{h}^{-1}$ was observed at $65 \mathrm{~m}$ in the Northern Basin. During the dry season, natural denitrification rates were lower, due to low $\mathrm{NO}_{3}^{-}$concentrations. Almost no natural anammox was observed (maximum rate of $0.01 \mathrm{nmol} \mathrm{N}$ produced $\mathrm{L}^{-1} \mathrm{~h}^{-1}$ ), and natural DNRA rates were also clearly lower (maximum rate of $0.7 \mathrm{nmol} \mathrm{N}$ produced $\mathrm{L}^{-1} \mathrm{~h}^{-1}$ ).

The maximum depth-integrated natural denitrification rate was observed in the Northern Basin and can be estimated to $0.01 \mathrm{mmol} \mathrm{N} \mathrm{m}^{-2} \mathrm{~d}^{-1}$ (Supporting Information Table S2), while the depth-integrated natural DNRA rate observed in the Northern Basin was estimated to only $0.0001 \mathrm{mmol} \mathrm{N} \mathrm{m} \mathrm{m}^{-2} \mathrm{~d}^{-1}$ (integration from $40 \mathrm{~m}$ to $65 \mathrm{~m}$ depth). The maximum depth-integrated natural DNRA rate was observed in the Southern Basin and was estimated to $0.0002 \mathrm{mmol} \mathrm{N} \mathrm{m}^{-2} \mathrm{~d}^{-1}$. Dalsgaard et al. (2013) also calculated depth-integrated in situ denitrification rates in the Baltic Sea, which ranged from $0.06 \mathrm{mmol} \mathrm{N} \mathrm{m} \mathrm{N}^{-2} \mathrm{~d}^{-1}$ to 2.11 mmol $\mathrm{N} \mathrm{m}^{-2} \mathrm{~d}^{-1}$. Schubert et al. (2006) calculated depthintegrated denitrification rates of $2.4 \mathrm{mmol} \mathrm{N} \mathrm{m} \mathrm{m}^{-2} \mathrm{~d}^{-1}$ in Lake Tanganyika, but their calculations were based on potential denitrification rates and they admit that their calculations should be taken with caution, since they only performed one measurement. Depth-integrated potential denitrification rates in Lake Kivu were higher than natural rates, but remained low, with a maximum of $0.05 \mathrm{mmol} \mathrm{N}$ $\mathrm{m}^{-2} \mathrm{~d}^{-1}$ (in the Northern Basin).

We investigated if substrates fluxes were sufficient to explain natural and potential denitrification rates observed. As the nitracline is spatially limited, it is difficult to precisely calculate $\mathrm{NO}_{3}^{-}$fluxes, and would have required dedicated 
nitrification measurements. We can calculate $\mathrm{NH}_{4}^{+}$diffusion fluxes, which in turn sustain $\mathrm{NO}_{3}^{-}$concentrations through nitrification. As shown in Supporting Information Table S2, upward $\mathrm{NH}_{4}^{+}$fluxes were always sufficient to explain the denitrification rates observed during this study.

Denitrification and anammox processes are limited by substrate availability

We determined the effect of substrate availability on $\mathrm{NO}_{3}^{-}$ reduction. In the Northern Basin, during the rainy season, ${ }^{15} \mathrm{NO}_{3}^{-}$labeling experiments were conducted with amendments of ${ }^{15} \mathrm{NO}_{3}^{-}$of different initial concentrations. These experiments were conducted at depths of $55 \mathrm{~m}, 60 \mathrm{~m}$, and $65 \mathrm{~m}$ (Fig. 4). Denitrification rates increased with increasing ${ }^{15} \mathrm{NO}_{3}^{-}$concentrations, at all depths measured. The maximum denitrification rate $\left(536 \mathrm{nmol} \mathrm{N}\right.$ produced $\mathrm{L}^{-1} \mathrm{~h}^{-1}$, $\mathrm{N}_{2}+\mathrm{N}_{2} \mathrm{O}$ ) was observed at $60 \mathrm{~m}$ depth with a final ${ }^{15} \mathrm{NO}_{3}^{-}$ concentration of $10 \mu \mathrm{mol} \mathrm{L}{ }^{-1}$. No anammox was observed at the depths of $55 \mathrm{~m}$ and $60 \mathrm{~m}$, while rates of anammox increased with increasing ${ }^{15} \mathrm{NO}_{3}^{-}$concentrations up to 5.2 nmol $\mathrm{N}$ produced $\mathrm{L}^{-1} \mathrm{~h}^{-1}$ with $10 \mu \mathrm{mol} \mathrm{L}{ }^{-1}$, at $65 \mathrm{~m}$. These results strongly suggest that denitrification in Lake Kivu is limited by $\mathrm{NO}_{3}^{-}$concentrations, and likewise, that anammox is probably limited by the supply of $\mathrm{NO}_{2}^{-}$, through partial denitrification. Experiments amended with ${ }^{15} \mathrm{NH}_{4}^{+}$suggest that anammox in the Southern Basin is co-limited by $\mathrm{NH}_{4}^{+}$. Indeed, these experiments revealed high rates of anammox in the Southern Basin (Fig. 3u), while no anammox was observed in the Northern Basin. Anammox rates were higher (up to $15 \mathrm{nmol} \mathrm{N}$ produced $\mathrm{L}^{-1} \mathrm{~h}^{-1}$ ) than those measured with ${ }^{15} \mathrm{NO}_{3}^{-}$, and were located at shallower depths (at $47.5 \mathrm{~m}$ ), where $\mathrm{NH}_{4}^{+}$concentrations were very low (less than $\left.1 \mu \mathrm{mol} \mathrm{L}{ }^{-1}\right)$.

Competition occurs between denitrification, anammox, and DNRA

Denitrification, anammox, and DNRA all compete for $\mathrm{NO}_{3}^{-}$, and competition may thus appear between the different processes. During our study, we observed a competitive relationship between denitrification and DNRA, since for both stations, higher denitrification rates corresponded to the lower DNRA rates (Fig. 5a). Also, competition between anammox and DNRA seemed to occur, since anammox rates tended to be lower when DNRA rates were higher (Fig. 5b). Although DNRA can, in theory, fuel the anammox bacterial community in $\mathrm{NH}_{4}^{+}$, they can also enter in competition for $\mathrm{NO}_{2}^{-}$and $\mathrm{NO}_{3}^{-}$. At depths where the different processes were measured, $\mathrm{NH}_{4}^{+}$was not limiting with concentrations ranging between $2 \mu \mathrm{mol} \mathrm{L}{ }^{-1}$ and $43 \mu \mathrm{mol} \mathrm{L}^{-1}$ (so the supply of $\mathrm{NH}_{4}^{+}$by DNRA was not required for anammox), contrary to the low $\mathrm{NO}_{2}^{-}\left(0.02-1 \mu \mathrm{mol} \mathrm{L}{ }^{-1}\right)$, and $\mathrm{NO}_{3}^{-}\left(0.2-3 \mu \mathrm{mol} \mathrm{L}{ }^{-1}\right)$ concentrations, explaining the competitive relationship. On the contrary, anammox seemed not to enter in competition with denitrification for substrates, since anammox rates tended to be higher when denitrification rates were higher
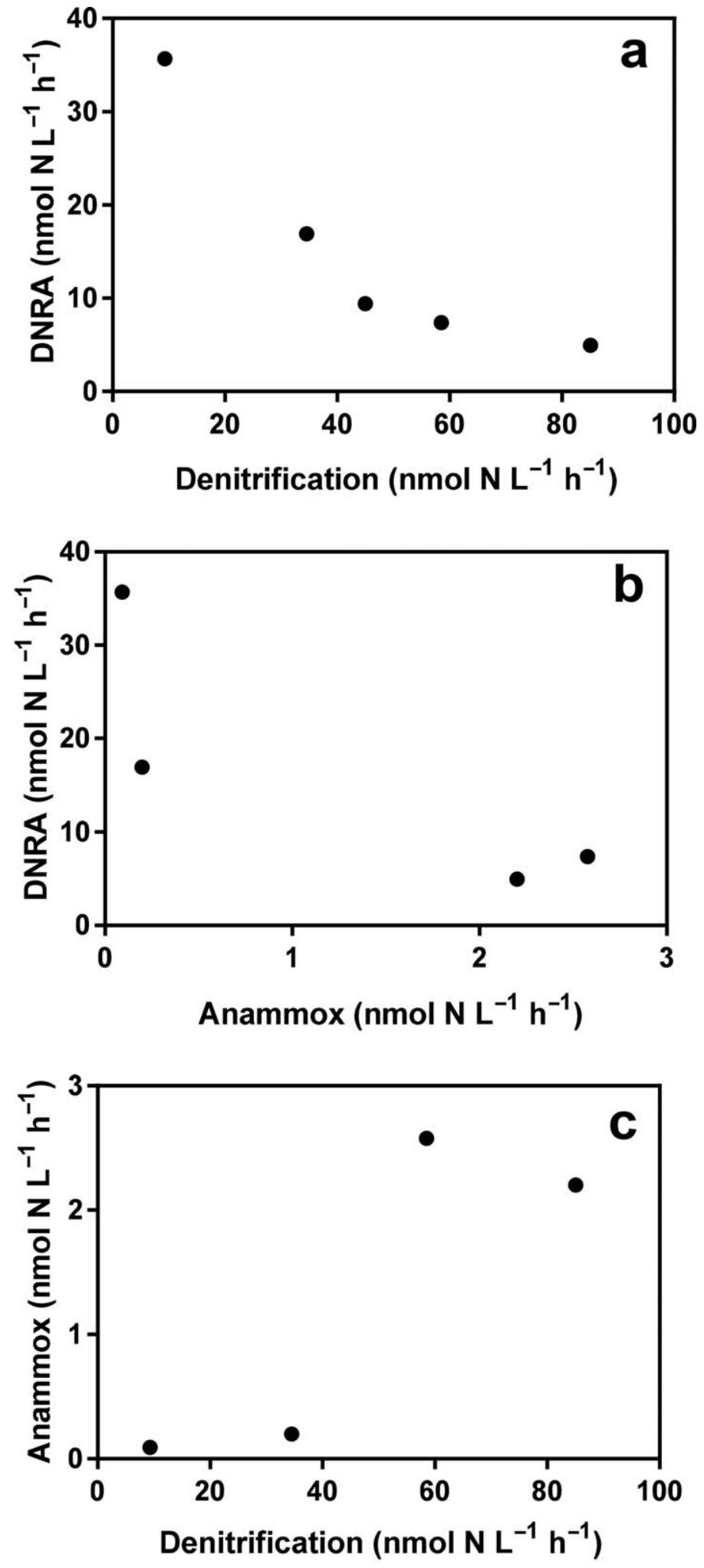

Fig. 5. Correlation between (a) DNRA and denitrification rates, (b) DNRA and anammox rates and (c) Anammox and denitrification rates (nmol $\mathrm{N}$ produced $\mathrm{L}^{-1} \mathrm{~h}^{-1}$ ) at both stations and during both seasons. 
(Fig. 5c). This suggests that anammox bacteria may gain benefit from $\mathrm{NO}_{2}^{-}$produced as intermediate during the denitrification process.

\section{The effect of $\mathrm{H}_{2} \mathrm{~S}$ on denitrification, anammox, and DNRA}

All rates reported in this section are potential rates, measured in the incubations with ${ }^{15} \mathrm{NO}_{3}^{-}$and $\mathrm{H}_{2} \mathrm{~S}$ added, during the rainy season.

In the Northern Basin, the addition of $\mathrm{H}_{2} \mathrm{~S}$ was followed by an increase of denitrification, anammox, and DNRA rates at almost all depths measured, except at $65 \mathrm{~m}$ where denitrification and DNRA rates slightly decreased. In particular, anammox rate increased up to $24 \mathrm{nmol} \mathrm{N}$ produced $\mathrm{L}^{-1} \mathrm{~h}^{-1}$ at $50 \mathrm{~m}$, where the contribution of anammox to $\mathrm{N}_{2}$ production reached 32\% (Table 1). Some studies in marine anoxic environments have suggested an inhibitory effect of $\mathrm{H}_{2} \mathrm{~S}$ on anammox (Dalsgaard et al. 2003; Jensen et al. 2008, 2009). However, other studies conducted in wastewater bed reactors and in laboratory cultures showed that anammox bacteria tolerate $\mathrm{H}_{2} \mathrm{~S}$ and can even be stimulated by $\mathrm{H}_{2} \mathrm{~S}$ (Kalyuzhnyi et al. 2006; Jung et al. 2007; Russ et al. 2014). The study of Wenk et al. (2013) on Lake Lugano, which used the same incubation method, also showed that anammox was stimulated by the addition of $\mathrm{H}_{2} \mathrm{~S}$. To explain anammox activity in the presence of $\mathrm{H}_{2} \mathrm{~S}$, they suggested that anammox bacteria lived in aggregates with chemolithotrophic denitrifying bacteria and thus in the presence of lower concentrations of $\mathrm{H}_{2} \mathrm{~S}$ following its consumption by the denitrifying bacteria. The latter would also produce $\mathrm{NO}_{2}^{-}$, which would in turn stimulate anammox. In our study, the addition of $\mathrm{H}_{2} \mathrm{~S}$ also stimulated denitrification in the Northern Basin, suggesting the occurrence of chemolithotrophic denitrification. We also observed an increased production of $\mathrm{N}_{2} \mathrm{O}$ with the addition of $\mathrm{H}_{2} \mathrm{~S}$ (Table 2), suggesting the occurrence of chemolithotrophic denitrification, which stimulates $\mathrm{NO}_{3}^{-}$and $\mathrm{NO}_{2}^{-}$ reduction relative to $\mathrm{N}_{2} \mathrm{O}$ reduction, leading to a higher $\mathrm{N}_{2} \mathrm{O}$ production, but a T-student test showed that these increases were not significant $(p=0.06)$. Bacterial communities potentially capable to perform chemolithotrophic denitrification seem to be present in the water column of Lake Kivu. Indeed, İnceoglu et al. (2015b) put in evidence the presence of Epsilonproteobacteria and Gammaproteobacteria, two classes among which bacteria capable of $\mathrm{HS}^{-}$oxidation, such as Sulfurimonas sp., Sulfuricurvum sp., Thiothrix sp., and Thiomicrospira sp. (e.g., Larkin and Strohl 1983; Friedrich et al. 2005; Ghosh and Dam 2009). Inceoğlu et al. (2015b) also showed that Betaproteobacteria were well represented, among which Thiobacillus sp., capable to perform denitrification coupled to $\mathrm{H}_{2} \mathrm{~S}$ oxidation.

In the Southern Basin, $\mathrm{H}_{2} \mathrm{~S}$ experiments were only performed at four depths $(45 \mathrm{~m}, 47.5 \mathrm{~m}, 50 \mathrm{~m}$, and $55 \mathrm{~m}$ ) for denitrification and anammox, and at three depths $(47.5 \mathrm{~m}$,
Table 2. Relative contribution (\% $\%$ standard deviation) of $\mathrm{N}_{2}$ production compared with $\mathrm{N}_{2}+\mathrm{N}_{2} \mathrm{O}$ production without and with $\mathrm{H}_{2} \mathrm{~S}$ added, in rainy season, for depths with significant $(p<0.05)$ rates of denitrification.

\begin{tabular}{lcc}
\hline & Without $\mathrm{H}_{2} \mathrm{~S}$ & With $\mathrm{H}_{2} \mathrm{~S}$ \\
\hline Northern Basin & & \\
50 & $100 \pm 0$ & $92 \pm 6$ \\
55 & $100 \pm 0$ & $100 \pm 0$ \\
60 & $96 \pm 3$ & $88 \pm 5$ \\
65 & $99 \pm 3$ & $47 \pm 24$ \\
Southern Basin & & \\
47.5 & $100 \pm 0$ & Not detected \\
50 & $100 \pm 0$ & $100 \pm 0$ \\
55 & $99 \pm 2$ & $100 \pm 2$ \\
60 & $74 \pm 27$ & n.d \\
65 & $84 \pm 2$ & n.d \\
70 & $94 \pm 1$ & n.d \\
\hline
\end{tabular}

n.d., not determined.

$50 \mathrm{~m}$, and $55 \mathrm{~m}$ ) for DNRA. In contrast to the Northern Basin, the addition of $\mathrm{H}_{2} \mathrm{~S}$ tended to decrease denitrification rates, while no effect was observed on anammox rates, which remained below detection. On the contrary, the addition of $\mathrm{H}_{2} \mathrm{~S}$ tended to stimulate DNRA rates. An experimental error, such as an inhibition of denitrification by the addition of small quantities of oxygen, seems very unlikely, since a pre-incubation period of $12 \mathrm{~h}$ after filling the incubation vials was respected before the start of the experiment, to allow the consumption of the potential external oxygen artificially introduced. Furthermore, the same sampling protocol was use in stations in both basins and all sampling expeditions. Alternatively, denitrifiers can compete for $\mathrm{NO}_{3}^{-}$ and $\mathrm{NO}_{2}^{-}$with DNRA and anammox bacteria. The inhibition of denitrification in presence of $\mathrm{H}_{2} \mathrm{~S}$ has been frequently reported (e.g., Jorgensen 1989; Joye and Hollibaugh 1995; An and Gardner 2002) but it is now established that denitrification can be coupled with $\mathrm{H}_{2} \mathrm{~S}$ oxidation (e.g., Brettar and Rheinheimer 1991; Burgin and Hamilton 2008; Jensen et al. 2009). So, it seems that the apparent inhibition of denitrification (actually the inhibition of $\mathrm{N}_{2} \mathrm{O}$ reduction to $\mathrm{N}_{2}$ ) at high $\mathrm{H}_{2} \mathrm{~S}$ concentrations could be due to a competition with DNRA for substrates. Indeed, several studies suggest that DNRA can be enhanced at high $\mathrm{H}_{2} \mathrm{~S}$ concentrations (e.g., Brunet and Garcia-Gil 1996; Rysgaard et al. 1996; Sayama et al. 2005) and becomes more competitive than denitrification. During our measurements, DNRA rates tended to increase when $\mathrm{H}_{2} \mathrm{~S}$ was added. The fact that denitrification rates decreased with the addition of $\mathrm{H}_{2} \mathrm{~S}$ only in the Southern Basin could be explained by the higher importance of DNRA in the Southern Basin (reflected by higher DNRA rates in "normal" conditions, without $\mathrm{H}_{2} \mathrm{~S}$ added), and so by a stronger competition. 


\section{Spatial heterogeneity}

During this study, we put in evidence important differences between the Northern and the Southern Basin of Lake Kivu. Without $\mathrm{H}_{2} \mathrm{~S}$ added, denitrification tended to be higher in the Northern Basin, while anammox and DNRA tended to be more important in the Southern Basin. The treatment with ${ }^{15} \mathrm{NH}_{4}^{+}$added also showed important potential anammox rates only in the Southern Basin. However, differences in bacterial communities between both basins are not significant, since relative abundances of bacterial community capable of DNRA was estimated to be up to $8 \%$ and $13 \%$ (means of both campaigns) in the Northern and Southern Basins, respectively, while relative abundance of denitrifying community was estimated to $35 \%$ and $44 \%$. It seems unlikely that the small difference in term of the bacterial community composition is the only factor determining the different process rates observed in the Northern and Southern Basin. The two basins are morphometrically different: the water column in the Southern Basin seems to be more stable than the Northern Basin, explaining why anammox was more widespread in the Southern Basin, since anammox is a slow process requiring stable environmental conditions (Strous et al. 1999). Also, based upon $\mathrm{NH}_{4}^{+}$vertical profiles, it seems that $\mathrm{NH}_{4}^{+}$concentrations tend to be higher in the Southern Basin, probably linked to higher DNRA rates, what can influence anammox. Concerning heterotrophic denitrification and DNRA, it is difficult to explain differences observed with available data. We can hypothesize that organic matter supply is different between both basins, with higher supply in the Southern Basin, due to its smaller size. Indeed, due to higher proximity of surrounding land, allochthonous organic matter supply may be higher, especially during the rainy season. This would favor DNRA over denitrification (Kelso et al. 1997; Silver et al. 2001; Dong et al. 2011).

\section{Conclusions}

The present study reports the occurrence of denitrification, DNRA and anammox for the first time in Lake Kivu, and to our best knowledge, in the water column of a large tropical lake. We showed that these three processes can cooccur in the anoxic water column, although competition for substrates occurred. As in Lake Lugano (Wenk et al. 2013), we showed the co-occurrence of chemolithotrophic denitrification and anammox. Further studies are required to determine if aggregates between denitrifying bacteria and anammox bacteria are possible and if they are present in Lake Kivu, and to elucidate the competitive relationships between the three processes. During this study, we stimulated denitrification, anammox and DNRA rates by the addition of ${ }^{15} \mathrm{NO}_{3}^{-}$and ${ }^{15} \mathrm{NH}_{4}^{+}$. Even if agriculture around Lake Kivu is still traditional, population growth might lead to increased use of fertilizers, and thus of a higher $\mathrm{N}$ supply. Also, methane extraction from deep waters to produce electricity has started at industrial scale, and raising the problem of the disposal of the extracted nutrients-rich deep waters. The data of the processes reported in this manuscript could be thus used as baseline study and to calibrate models that address the future evolution of the lake.

\section{References}

An, S., and W. S. Gardner. 2002. Dissimilatory nitrate reduction to ammonium (DNRA) as a nitrogen link, versus denitrification as a sink in a shallow estuary (Laguna Madre/Baffin Bay, Texas). Mar. Ecol. Prog. Ser. 237: 4150. doi:10.3354/meps 237041

APHA. 1998. Standard methods for the examination of water and wastewater. APHA.

Bokranz, M., J. Katz, I. Schröder, A. M. Roberton, and A. Kröger. 1983. Energy metabolism and biosynthesis of Vibrio succinogenes growing with nitrate or nitrite as terminal electron acceptor. Arch. Microbiol. 135: 36-41. doi: 10.1007/BF00419479

Borges, A. V., and others. 2015. Globally significant greenhouse-gas emissions from African inland waters. Nat. Geosci. 8: 637-642. doi:10.1038/ngeo2486

Braman, R. S., and S. A. Hendrix. 1989. Nanogram nitrite and nitrate determination in environmental and biological materials by vanadium(III) reduction with chemiluminescence detection. Anal. Chem. 61: 2715-2718. doi: 10.1021/ac00199a007

Brettar, I., and G. Rheinheimer. 1991. Denitrification in the Central Baltic: Evidence for H2S-oxidation as motor of denitrification at the oxic-anoxic interface. Mar. Ecol. Prog. Ser. 77: 157-169. doi:10.3354/meps077157

Brunet, R. C., and L. J. Garcia-Gil. 1996. Sulfide-induced dissimilatory nitrate reduction to ammonia in anaerobic freshwater sediments. FEMS Microbiol. Ecol. 21: 131-138. doi:10.1016/0168-6496(96)00051-7

Burgin, A. J., and S. K. Hamilton. 2008. $\mathrm{NO}_{3}^{-}$-driven $\mathrm{SO}_{4}^{2-}$ production in freshwater ecosystems: Implications for $\mathrm{N}$ and S cycling. Ecosystems 11: 908-922. doi:10.1007/ s10021-008-9169-5

Canfield, D. E., F. J. Stewart, B. Thamdrup, L. De Brabandere, T. Dalsgaard, E. F. Delong, N. P. Revsbech, and O. Ulloa. 2010. A cryptic sulfur cycle in oxygen-minimum-zone waters off the Chilean coast. Science 330: 1375-1378. doi:10.1126/science.1196889

Claus, G., and H. J. Kutzner. 1985. Physiology and kinetics of autotrophic denitrification by Thiobacillus denitrificans. Appl. Microbiol. Biotechnol. 22: 283-288. doi: 10.1007/bf00252031

Cline, J. D. 1969. Spectrophotometric determination of hydrogen sulfide in natural waters. Limnol. Oceanogr. 14: 454-458. doi:10.4319/1o.1969.14.3.0454

Codispoti, L., J. Elkins, T. Yoshinari, G. Friederich, C. Sakamoto, and T. Packard. 1992. On the nitrous oxide 
flux from productive regions that contain low oxygen waters, p. 271-284. In B. N. Desai [ed.] Oceanography of the Indian Ocean. Balkema.

Dalsgaard, T., and F. Bak. 1994. Nitrate reduction in a sulfate-reducing bacterium, Desulfovibrio desulfuricans, isolated from rice paddy soil: Sulfide inhibition, kinetics, and regulation. Appl. Environ. Microbiol. 60: 291-297.

Dalsgaard, T., D. E. Canfield, J. Petersen, B. Thamdrup, and J. Acuña-González. 2003. N2 production by the anammox reaction in the anoxic water column of Golfo Dulce, Costa Rica. Nature 422: 606-608. doi:10.1038/nature01526

Dalsgaard, T., L. De Brabandere, and P. O. J. Hall. 2013. Denitrification in the water column of the central Baltic Sea. Geochim. Cosmochim. Acta 106: 247-260. doi: 10.1016/j.gca.2012.12.038

Darchambeau, F., H. Sarmento, and J. P. Descy. 2014. Primary production in a tropical large lake: The role of phytoplankton composition. Sci. Total Environ. 473-474: 178-188. doi:10.1016/j.scitotenv.2013.12.036

Descy, J.-P., F. Darchambeau, and M. Schmid. 2012. Lake Kivu: Limnology and biogeochemistry of a tropical great lake. Springer.

Dong, L. F., M. N. Sobey, C. Smith, I. Rusmana, W. Phillips, A. Stott, A. M. Osborn, and D. B. Nedwell. 2011. Dissimilatory reduction of nitrate to ammonium (DNRA) not denitrification or anammox dominates benthic nitrate reduction in tropical estuaries. Limnol. Oceanogr. 56: 279-291. doi:10.4319/1o.2011.56.1.0279

Friedrich, C. G., F. Bardischewsky, D. Rother, A. Quentmeier, and J. Fischer. 2005. Prokaryotic sulfur oxidation. Curr. Opin. Microbiol. 8: 253-259. doi:10.1016/j.mib.2005. 04.005

Ghosh, W., and B. Dam. 2009. Biochemistry and molecular biology of lithotrophic sulfur oxidation by taxonomically and ecologically diverse bacteria and archaea. FEMS Microbiol. Rev. 33: 999-1043. doi:10.1111/j.1574-6976. 2009.00187.x

Hamersley, M. R., D. Woebken, B. Boehrer, M. Schultze, G. Lavik, and M. M. M. Kuypers. 2009. Water column anammox and denitrification in a temperate permanently stratified lake (Lake Rassnitzer, Germany). Syst. Appl. Microbiol. 32: 571-582. doi:10.1016/j.syapm.2009.07.009

Hulth, S., R. C. Aller, D. E. Canfield, T. Dalsgaard, P. Engström, F. Gilbert, K. Sundbäck, and B. Thamdrup. 2005. Nitrogen removal in marine environments: Recent findings and future research challenges. Mar. Chem. 94: 125-145. doi:10.1016/j.marchem.2004.07.013

İnceoğlu, Ö., and others. 2015a. Vertical distribution of functional potential and active microbial communities in meromictic Lake Kivu. Microb. Ecol. 70: 596-611. doi: 10.1007/s00248-015-0612-9

İnceoğlu, Ö., M. Llirós, T. García-Armisen, S. A. Crowe, C. Michiels, F. Darchambeau, J.-P. Descy, and P. Servais. $2015 b$. Distribution of bacteria and archaea in meromictic tropical Lake Kivu (Africa). Aquat. Microb. Ecol. 74: 215233. doi:10.3354/ame01737

IPCC. 2013. Climate Change 2013: The Physical Science Basis. Contribution of Working Group I to the Fifth Assessment Report of the Intergovernmental Panel on Climate Change, 1535 p. Cambridge Univ. Press.

Jensen, M. M., M. M. M. Kuypers, G. Lavik, and B. Thamdrup. 2008. Rates and regulation of anaerobic ammonium oxidation and denitrification in the Black Sea. Limnol. Oceanogr. 53: 23-36. doi:10.4319/1o.2008.53.1.0023

Jensen, M. M., J. Petersen, T. Dalsgaard, and B. Thamdrup. 2009. Pathways, rates, and regulation of $\mathrm{N} 2$ production in the chemocline of an anoxic basin, Mariager Fjord, Denmark. Mar. Chem. 113: 102-113. doi:10.1016/j.marchem. 2009.01.002

Jetten, M. S. M., and others. 1998. The anaerobic oxidation of ammonium. FEMS Microbiol. Rev. 22: 421-437. doi: 10.1111/j.1574-6976.1998.tb00379.x

Jetten, M. S. M., M. Wagner, J. Fuerst, M. van Loosdrecht, G. Kuenen, and M. Strous. 2001. Microbiology and application of the anaerobic ammonium oxidation ('anammox') process. Curr. Opin. Biotechnol. 12: 283-288. doi: 10.1016/S0958-1669(00)00211-1

Jin, R. C., G. F. Yang, J. J. Yu, and P. Zheng. 2012. The inhibition of the Anammox process: A review. Chem. Eng. J. 197: 67-79. doi:10.1016/j.cej.2012.05.014

Jorgensen, K. S. 1989. Annual pattern of denitrification and nitrate ammonification in estuarine sediment. Appl. Environ. Microbiol. 55: 1841-1847.

Joye, S. B., and J. T. Hollibaugh. 1995. Influence of sulfide inhibition of nitrification on nitrogen regeneration in sediments. Science 270: 623-625. doi:10.1126/science. 270.5236 .623

Jung, J. Y., S. H. Kang, Y. C. Chung, and D. H. Ahn. 2007. Factors affecting the activity of anammox bacteria during start up in the continuous culture reactor. Water Sci. Technol. 55: 459-468. doi:10.2166/wst.2007.023

Kalyuzhnyi, S., M. Gladchenko, A. Mulder, and B. Versprille. 2006. DEAMOX-New biological nitrogen removal process based on anaerobic ammonia oxidation coupled to sulphide-driven conversion of nitrate into nitrite. Water Res. 40: 3637-3645. doi:10.1016/j.watres.2006.06.010

Kartal, B., M. M. M. Kuypers, G. Lavik, J. Schalk, H. J. M. Op Den Camp, M. S. M. Jetten, and M. Strous. 2007. Anammox bacteria disguised as denitrifiers: Nitrate reduction to dinitrogen gas via nitrite and ammonium. Environ. Microbiol. 9: 635-642. doi:10.1111/j.1462-2920.2006.01183.x

Kelso, B., R. V. Smith, R. J. Laughlin, and S. D. Lennox. 1997. Dissimilatory nitrate reduction in anaerobic sediments leading to river nitrite accumulation. Appl. Environ. Microbiol. 63: 4679-4685.

Kirchman, D. L. 2008. Microbial ecology of the oceans. John Wiley \& Sons.

Knowles, R., and T. H. Blackburn. 1993. Nitrogen isotope techniques. Academic Press. 
Kuypers, M. M., G. Lavik, D. Woebken, M. Schmid, B. M. Fuchs, R. Amann, B. B. Jørgensen, and M. S. Jetten. 2005. Massive nitrogen loss from the Benguela upwelling system through anaerobic ammonium oxidation. Proc. Natl. Acad. Sci. USA 102: 6478-6483. doi:10.1073/pnas. 0502088102

Larkin, J., and W. Strohl. 1983. Beggiatoa, thiothrix, and thioploca. Annu. Rev. Microbiol. 37: 341-367. doi:10.1146/ annurev.mi.37.100183.002013

Lavik, G., and others. 2009. Detoxification of sulphidic African shelf waters by blooming chemolithotrophs. Nature 457: 581-584. doi:10.1038/nature07588

Lewis, W. M., Jr. 1987. Tropical limnology. Annu. Rev. Ecol. Evol. Syst. 18: 159-184. doi:10.1146/annurev.es.18. 110187.001111

Lewis, W. M., Jr. 2000. Basis for the protection and management of tropical lakes. Lake Reserv. Manag. 5: 35-48. doi: 10.1046/j.1440-1770.2000.00091.X

Llirós, M., F. Gich, A. Plasencia, J. C. Auguet, F. Darchambeau, E. O. Casamayor, J. P. Descy, and C. Borrego. 2010. Vertical distribution of ammonia-oxidizing crenarchaeota and methanogens in the epipelagic waters of Lake Kivu (Rwanda-Democratic Republic of the Congo). Appl. Environ. Microbiol. 76: 6853-6863. doi:10.1128/ AEM.02864-09

Miranda, K. M., M. G. Espey, and D. A. Wink. 2001. A rapid, simple spectrophotometric method for simultaneous detection of nitrate and nitrite. Nitric Oxide 5: 62-71. doi:10.1006/niox.2000.0319

Morana, C., F. A. Roland, S. A. Crowe, M. Llirós, A. V. Borges, F. Darchambeau, and S. Bouillon. 2016. Chemoautotrophy and anoxygenic photosynthesis within the water column of a large meromictic tropical lake (Lake Kivu, East Africa). Limnol. Oceanogr. 61: 1424-1437. doi: 10.1002/lno.10304

Pasche, N., and others. 2011. Methane sources and sinks in Lake Kivu. J. Geophys. Res. Biogeosci. 116: G03006. doi: 10.1029/2011JG001690

Roland, F. A. E., F. Darchambeau, C. Morana, and A. V. Borges. 2016. Nitrous oxide and methane seasonal variability in the epilimnion of a large tropical meromictic lake (Lake Kivu, East-Africa). Aquat. Sci. 79: 209-218. doi: 10.1007/s00027-016-0491-2

Russ, L., D. R. Speth, M. S. Jetten, H. J. Op den Camp, and B. Kartal. 2014. Interactions between anaerobic ammonium and sulfur-oxidizing bacteria in a laboratory scale model system. Environ. Microbiol. 16: 3487-3498. doi:10.1111/ 1462-2920.12487

Rysgaard, S., N. Risgaard-Petersen, and N. P. Sloth. 1996. Nitrification, denitrification, and nitrate ammonification in sediments of two coastal lagoons in Southern France. Hydrobiologia 329: 133-141. doi:10.1007/BF00034553

Saad, O.A.L.O., and R. Conrad. 1993. Temperature dependence of nitrification, denitrification, and turnover of nitric oxide in different soils. Biol. Fertil. Soils 15: 21-27. doi:10.1007/BF00336283

Sayama, M., N. Risgaard-Petersen, L. P. Nielsen, H. Fossing, and P. B. Christensen. 2005. Impact of bacterial NO3 transport on sediment biogeochemistry. Appl. Environ. Microbiol. 71: 7575-7577. doi:10.1128/AEM.71.11.75757577.2005

Schmid, M., M. Halbwachs, B. Wehrli, and A. Wüest. 2005. Weak mixing in Lake Kivu: New insights indicate increasing risk of uncontrolled gas eruption. Geochem. Geophys. Geosyst. 6. doi:10.1029/2004GC000892

Schubert, C. J., E. Durisch-Kaiser, B. Wehrli, B. Thamdrup, P. Lam, and M. M. M. Kuypers. 2006. Anaerobic ammonium oxidation in a tropical freshwater system (Lake Tanganyika). Environ. Microbiol. 8: 1857-1863. doi:10.1111/ j.1462-2920.2006.01074.x

Seitzinger, S. P. 1988. Denitrification in freshwater and coastal marine ecosystems: Ecological and geochemical significance. Limnol. Oceanogr. 33: 702-724. doi: 10.4319/lo.1988.33.4part2.0702

Silver, W. L., D. J. Herman, and M. K. Firestone. 2001. Dissimilatory nitrate reduction to ammonium in upland tropical forest soils. Ecology 82: 2410-2416. doi:10.2307/ 2679925

Strohm, T. O., B. Griffin, W. G. Zumft, and B. Schink. 2007. Growth yields in bacterial denitrification and nitrate ammonification. Appl. Environ. Microbiol. 73: 14201424. doi:10.1128/AEM.02508-06

Strous, M., J. G. Kuenen, and M. S. Jetten. 1999. Key physiology of anaerobic ammonium oxidation. Appl. Environ. Microbiol. 65: 3248-3250.

Thamdrup, B., and T. Dalsgaard. 2002. Production of N2 through anaerobic ammonium oxidation coupled to nitrate reduction in marine sediments. Appl. Environ. Microbiol. 68: 1312-1318. doi:10.1128/AEM.68.3

Thamdrup, B., T. Dalsgaard, M. M. Jensen, O. Ulloa, L. Farías, and R. Escribano. 2006. Anaerobic ammonium oxidation in the oxygen-deficient waters off northern Chile. Limnol. Oceanogr. 51: 2145-2156. doi:10.4319/lo.2006. 51.5.2145

Tiedje, J. M. 1994. Denitrifiers, p. 245-267. In Bottomley, P.S., Angle, J. S., and Weaver, R. W. [eds.], Methods of soil analysis: Part 2-microbiological and biochemical properties. SSSA Book Series, 5.2, Soil Sci. Soc. Am., Madison, WI.

Van Hulle, S. W. H., H. J. P. Vandeweyer, B. D. Meesschaert, P. A. Vanrolleghem, P. Dejans, and A. Dumoulin. 2010. Engineering aspects and practical application of autotrophic nitrogen removal from nitrogen rich streams. Chem. Eng. J. 162: 1-20. doi:10.1016/ j.cej.2010.05.037

Wenk, C. B., J. Blees, J. Zopfi, M. Veronesi, A. Bourbonnais, C. J. Schubert, H. Niemann, and M. F. Lehmann. 2013. Anaerobic ammonium oxidation 
(anammox) bacteria and sulfide-dependent denitrifiers coexist in the water column of a meromictic southalpine lake. Limnol. Oceanogr. 58: 1-12. doi:10.4319/ lo.2013.58.1.0001

Westwood, D. 1981. Ammonia in waters. In Methods for the examination of waters and associated materials. HMSO.

\section{Acknowledgments}

We thank Boniface Kaningini, Pascal Isumbisho, Georges Alunga, Fabrice Muvundja, and Pascal Masilya (Institut Supérieur Pédagogique, Bukavu, DRC) for logistic support during the cruises, and the Rwanda Energy Company for the access to their platform for the sampling. This study was funded by the Belgian Federal Science Policy Office (BELSPO, Belgium) under the EAGLES (East African Great Lake Ecosystem Sensitivity to Changes, SD/AR/02A) project, by the Fonds National de la
Recherche Scientifique (FNRS) under the MICKI (Microbial diversity and processes in Lake Kivu, 1715859) project, and contributes to the European Research Council (ERC) starting grant project AFRIVAL (African river basins: Catchment-scale carbon fluxes and transformations, 240002). AVB is a senior research associate to the FNRS. F.A.E.R benefited from a Ph.D. grant from the FNRS (Fonds pour la formation à la Recherche dans I'Industrie et dans I'Agriculture (FRIA)), and is post-doctoral researcher at the FNRS.

\section{Conflict of Interest}

None declared.

Submitted 06 September 2016 Revised 27 March 2017; 24 July 2017 Accepted 25 July 2017

Associate editor: John Melack 